INTERSTITIAL LUNG DISEASE

\title{
In vivo IL-10 gene delivery attenuates bleomycin induced pulmonary fibrosis by inhibiting the production and activation of TGF- $\beta$ in the lung
}

\author{
K Nakagome, M Dohi, K Okunishi, R Tanaka, J Miyazaki, K Yamamoto
}

Thorax 2006;61:886-894. doi: 10.1136/thx.2005.056317

See end of article for authors' affiliations

Correspondence to

Correspondence to: Division, Department of

Allergy and

Rheumatology, Graduate School of Medicine,

University of Tokyo, 7-3-1

Hongo, Bunkyo-ku, Tokyo

113-8655, Japan;

mdohi-tky@umin.ac.jp

Received

28 December 2005

Accepted 7 June 2006

Published Online First

29 June 2006
Backgroud: Idiopathic pulmonary fibrosis is a devastating disorder for which there is no effective treatment. Transforming growth factor (TGF)- $\beta$ plays a critical role in provoking fibrosis. Interleukin (IL)-10 is a potent immunosuppressive cytokine but its effect on the fibrosing process is unclear. A study was undertaken to examine whether IL-10 affects the production and activation of TGF- $\beta$ and thus can attenuate the fibrosis.

Methods: Mice were given an intratracheal injection of bleomycin. On day 1 or 14, IL-10 gene was delivered by rapid intravenous injection of Ringer's solution containing plasmid. Two weeks after the plasmid injection the mice were examined for fibrosis. The effect of IL-10 on TGF- $\beta$ production by alveolar macrophages was assessed.

Results: Even when delivered during the fibrosing phase, IL-10 gene significantly suppressed the pathological findings, hydroxyproline content, and production of both active and total forms of TGF- $\beta_{1}$ in the lung. Immunohistochemical analyses showed that alveolar macrophages were one of the major sources of TGF- $\beta_{1}$ and IL-10 diminished the intensity of the staining. IL-10 also suppressed the expression of $\alpha_{v} \beta_{6}$ integrin, a molecule that plays an important role in TGF- $\beta$ activation, on lung epithelial cells. Alveolar macrophages from bleomycin injected mice produced TGF- $\beta_{1}$ spontaneously ex vivo, which was significantly suppressed by treatment of the mice in vivo or by treatment of the explanted macrophages ex vivo with IL-10.

Conclusion: IL-10 suppresses the production and activation of TGF- $\beta$ in the lung and thus attenuates pulmonary fibrosis, even when delivered in the chronic phase. d diopathic pulmonary fibrosis (IPF) is a devastating disorder for which no effective treatment has been established. ${ }^{1}$ The role of inflammation in fibrosis has recently been questioned because inflammation is neither a major histopathological feature nor a good marker of activity or prognosis for IPF. $^{12}$ In addition, anti-inflammatory treatment have not proved to be effective. ${ }^{3}$ Recent advances in understanding the pathophysiology of IPF suggest that persistence and/or recurrence of injury may alter the microenvironment of the lung, especially the alveolar space, resulting in a dysregulated repair process which eventually leads to tissue fibrosis. ${ }^{14-6}$ The extent of fibroblastic foci, the most distinctive feature of ongoing pulmonary fibrosis, is predictive of survival in IPF. ${ }^{2}$ A therapeutic strategy directed at suppressing the fibrosis itself would therefore be appropriate. However, so far the efficacy of antifibrotic agents such as interferon (IFN)- $\gamma \mathrm{lb}$ or pirfenidone against IPF remains uncertain. $^{6-8}$

Bleomycin induced pulmonary fibrosis has been widely used as an experimental model..$^{9-12}$ However, it does not resemble human IPF in many respects. ${ }^{13}{ }^{14}$ For example, bleomycin induced pulmonary fibrosis is characterised by a uniform and bronchiolocentric distribution whereas IPF is characterised by temporal heterogeneity and predominance of subpleural lesions. It has a potential for recovery, unlike the human condition. Despite these limitations, the bleomycin model has contributed much to elucidating the molecular mechanisms of pulmonary fibrosis. ${ }^{9-12}$

Many factors play an important role in the development of fibrosis. They include profibrotic cytokines, chemokines, eicosanoids, fibrinolytic/fibrinogenic factors, matrix metalloproteinases and their inhibitors, and oxidative stress. ${ }^{4-6}$
Among them, transforming growth factor (TGF) $\beta$ is one of the central mediators. TGF- $\beta$ is known as an immunosuppressive cytokine. It suppresses proliferation of CD4+ T cells by inhibiting interleukin (IL)-2 production and maturation of dendritic cells by downregulating MHC class II expression. ${ }^{15}$ On the other hand, TGF- $\beta$ is a potent profibrotic cytokine; it enhances fibroblast chemotaxis and proliferation, and induces fibroblasts to synthesise collagen. ${ }^{16}$ TGF- $\beta$ therefore has a decisive role in many fibrotic disorders. In patients with IPF, TGF- $\beta$ is mainly produced by alveolar macrophages and is expressed in the fibroblastic foci. ${ }^{17}$ Recent microarray analyses have shown that TGF- $\beta_{1}$ related genes are upregulated in the bleomycin treated mouse lung. ${ }^{18}$ Giri and coworkers ${ }^{9}$ blocked the function of TGF- $\beta$ using a neutralising antibody and found that bleomycin induced fibrosis was suppressed. A chimeric TGF- $\beta_{1}$ soluble receptor reduced the intensity of bleomycin induced fibrosis in hamsters. ${ }^{10}$ Gene transfer of Smad7, an intracellular antagonist of TGF- $\beta$ signalling, also suppresses pulmonary fibrosis. ${ }^{11}$ These studies strongly indicate that TGF- $\beta$ could be directly involved in the fibrosing process.

The mechanism of TGF- $\beta$ activation in the lung has recently been highlighted. TGF- $\beta$ is synthesised as a precursor protein and is released in an inactive (latent) form. ${ }^{16}$ The activation occurs extracellularly. Latent TGF- $\beta$ can be activated by binding to $\alpha_{V} \beta_{6}$ integrin $^{19}$ or to thrombospondin- $1,{ }^{20}$ or by proteases such as plasmin. ${ }^{21}$ Among them, $\alpha_{V} \beta_{6}$ integrin plays an important role in animal models of lung fibrotic disease such

Abbreviations: BAL, bronchoalveolar lavage; hpf, high power fields; IL, interleukin; IPF, idiopathic pulmonary fibrosis; LPS, lipopolysaccharide; TGF, transforming growth factor 
as bleomycin induced pulmonary fibrosis ${ }^{19}$ and airway remodelling in allergic inflammation. ${ }^{22}$

IL-10 is an immunosuppressive cytokine which inhibits the production of many proinflammatory cytokines including IL$1 \alpha$, IL-6, IL-8, tumour necrosis factor (TNF)- $\alpha$, and granulocyte-macrophage colony stimulating factor (GM-CSF) from various cells. ${ }^{23}$ These in vitro studies raise the possibility that IL- 10 could be beneficial for the treatment of various immune diseases in vivo. ${ }^{24}{ }^{25}$ However, the relationship between IL-10 and pulmonary fibrosis is not fully clarified. In patients with IPF, production of IL-10 protein by alveolar macrophages did not increase, although expression of IL-10 mRNA in alveolar macrophages did. ${ }^{26}$ Concentrations of IL-10 protein in bronchoalveolar lavage (BAL) fluid of patients with IPF were lower than those of normal controls. ${ }^{27}$ These findings suggest that IL-10 might be lacking in patients with IPF. In the bleomycin induced mouse model the role of IL-10 in inflammation and fibrosis remains controversial, ${ }^{28-30}$ in particular, the effect of this cytokine on the production of TGF- $\beta$ in the lung has not been studied. Kradin and coworkers $^{28}$ suggested that IL-10 inhibits inflammation but does not affect fibrosis in the pulmonary response to bleomycin. They found that, although IL-10 deficient mice exhibited exaggerated bleomycin induced inflammation, the intensity of fibrosis was not different from that of wild-type mice. However, they examined only the role of endogenous IL-10 on inflammation and fibrosis and did not examine the effect of exogenous administration of IL- 10 .

Using a hydrodynamic based gene delivery system, we studied the effect of IL-10 on experimental pulmonary fibrosis and examined whether IL-10 played a part in the production of TGF- $\beta$ in the lung.

\section{METHODS}

Mice

Male C57BL/6 mice and C57BL/6-IL-10 $10^{-1-}$ mice were obtained from Charles River Japan Inc (Kanagawa, Japan) and the Jackson Laboratory (Bar Harbor, ME, USA), respectively. All animal experiments were approved by the Animal Research Ethics Board of the Department of Allergy and Rheumatology, University of Tokyo.

\section{Delivery of IL- 10 gene into mice}

The plasmid pCAGGS-IL-10 $0^{31}$ was amplified in Escherichia coli and purified with a Qiagen Endo Free plasmid Giga kit (Qiagen GmbH, Hilden, Germany). The plasmid pCAGGS was constructed by introducing the CAG (cytomegalovirus immediate-early enhancer-chicken $\beta$-actin hybrid) promoter, rabbit $\beta$-globin gene sequences including a polyadenylation signal, and an SV40 ori into pUC13. ${ }^{32}$ An empty pCAGGS plasmid was used as a control. Hydrodynamic based gene delivery by intravenous injection of the plasmid DNA was performed as described previously. ${ }^{31}{ }^{33}$ Briefly, plasmid DNA in lactated Ringer's solution $(0.1 \mathrm{ml} / \mathrm{g}$ body weight) was injected into the tail vein. The DNA injection was completed within 5 seconds. With this delivery system, the plasmid was trapped in the liver where it produced cytokine which then moved into the bloodstream and perfused the organs. ${ }^{31}{ }^{33}$ Mice received an intravenous injection of plasmid DNA ( $100 \mu \mathrm{g}$; pCAGGS-IL-10 or control pCAGGS) on day 0 .

To study the kinetics of IL-10 gene delivery, mice were killed on days $1,4,7,10,13$, and 20. Concentrations of IL-10 in serum and BAL fluid were measured using an ELISA kit (Pharmingen, San Diego, CA, USA) according to the manufacturer's instructions.

\section{Bleomycin administration and plasmid injection}

Seven week old animals received an intratracheal injection of $5 \mathrm{mg} / \mathrm{kg}$ bleomycin hydrochloride (kindly provided by
Nippon Kayaku, Tokyo, Japan) dissolved in $50 \mu$ l physiological saline on day 0 . Control mice received an intratracheal injection of saline on day 0. Some mice received plasmid DNA ( $100 \mu \mathrm{g}$; pCAGGS-IL-10 or control pCAGGS) or lactate alone on day 1 intravenously. To examine the dose dependent effect of IL-10 producing plasmid on the fibrosis, some mice received pCAGGS-IL-10 $(3 \mu \mathrm{g}, 10 \mu \mathrm{g}, 30 \mu \mathrm{g}$, or $100 \mu \mathrm{g}$, respectively) on day 1 . On day 7 , mice were killed to assess inflammation. On day 14, mice were killed to assess fibrosis of the lung. In some experiments mice received plasmid DNA or lactate alone on days 14,19 and 24 . On day 28 , mice were killed.

\section{BAL fluid analyses}

BAL fluid analyses were performed as described previously. ${ }^{33}{ }^{34}$ Briefly, the lungs were lavaged four times with physiological saline $(0.5 \mathrm{ml}$ each). The cell suspension was centrifuged at $300 \mathrm{~g}$ for 10 minutes at $4{ }^{\circ} \mathrm{C}$ and the supernatants were collected and stored at $-70^{\circ} \mathrm{C}$ for measurement of the concentration of TGF- $\beta_{1}$. The cells were resuspended in $1 \mathrm{ml}$ physiological saline with $1 \%$ bovine serum albumin (BSA; Wako, Osaka, Japan) and the total cell number was counted with a haemocytometer. Cytospin samples were prepared by centrifuging the suspensions at $300 \mathrm{rpm}$ for 10 minutes. On the basis of the findings made with DiffQuick staining (Kokusai-Shiyaku, Kobe, Japan), cell differentials were counted with at least 300 leucocytes in each sample. TGF- $\beta_{1}$ concentrations in BAL fluid were measured directly (before acidification) for detection of the active form of TGF- $\beta_{1}$ and after complete activation by acidification for the detection of total TGF- $\beta_{1}$ using an ELISA kit (R \& D Systems, Minneapolis, MN, USA). In this ELISA kit, TGF- $\beta_{1}$ antibody is not mouse specific and is reactive to human and rat TGF- $\beta_{1}$. The values were determined by comparison with a standard curve prepared from known concentrations of TGF- $\beta_{1}$. Levels of more than $7.8 \mathrm{pg} / \mathrm{ml}$ TGF- $\beta_{1}$ protein could be detected using this kit (data not shown). TGF- $\beta_{1}$ concentrations were measured two or three times using the ELISA kit and their reliability was confirmed.

\section{Histological examinations}

Histological examinations were performed as described previously. ${ }^{33}$ After perfusion with physiological saline, lung tissue was fixed by instilling 10\% neutralised buffered formalin (Wako) through the trachea and embedded in paraffin. Five $\mu \mathrm{m}$ thick sections were stained with haematoxylin and eosin or with Azan to evaluate collagen deposition. The extent of inflammation or fibrosis was evaluated using a previously reported scoring system with a slight modification. ${ }^{35}{ }^{36}$ Sections were viewed at a magnification of $\times 400$ and the lesions were defined as follows:

- Inflammation score: 0, absence of inflammation; 1, mild inflammatory changes (no obvious damage to the lung architecture); 2, moderate inflammatory injury (thickening of the alveolar septae); 3, severe inflammatory injury (pneumonitis that distorted the normal architecture).

- Fibrosis score: 0, absence of lesion; 1, occasional small localised subpleural foci; 2, thickening of interalveolar septa and subpleural foci; 3, continuous thickening of subpleural fibrous gangue and interalveolar septa.

Each section was evaluated by two researchers independently in a blind fashion and the mean value was used.

\section{Hydroxyproline assay}

The hydroxyproline assay was performed as described previously. ${ }^{12}$ Briefly, the left lung was cut out and hydrolysed in $2 \mathrm{ml}$ of $6 \mathrm{~N} \mathrm{HCl}$ (Wako) at $110^{\circ} \mathrm{C}$ for 12 hours. The $\mathrm{pH}$ of 
the samples was then adjusted to between 6 and 7. A $2 \mathrm{ml}$ aliquot from the total sample volume of $20 \mathrm{ml}$ was added to $1 \mathrm{ml}$ of $1.4 \%$ chloramine $\mathrm{T}$ (Wako) and incubated at room temperature for 20 minutes, then $1 \mathrm{ml}$ of $3.15 \mathrm{M}$ perchloric acid (Wako) was added and incubated for 5 minutes, followed by the addition of $1 \mathrm{ml}$ Erlich's solution ( $1 \mathrm{M} \mathrm{p}$ dimethylaminobenzaldehyde (Wako) in ethylene glycol monomethyl ether (Wako)). After incubation at $60^{\circ} \mathrm{C}$ for 20 minutes, absorbance was analysed at $570 \mathrm{~nm}$ with a Microplate Reader (Bio-Rad Laboratories, Hercules, CA, USA) and the amount of hydroxyproline was determined by comparison with a standard curve prepared from known concentrations of reagent hydroxyproline (Sigma, St Louis, MO, USA).

\section{Immunohistochemistry for TGF- $\beta_{1}$ and $\alpha_{V} \beta_{6}$ integrin}

Immunohistochemistry was performed using Vectastain ABC kits (Vector Laboratories, Burlingame, CA, USA) as described previously. ${ }^{12}$ Briefly, the tissue was deparaffinised and rehydrated with decreasing concentrations of ethyl alcohol. The slides were boiled in $0.05 \mathrm{M}$ citric acid for 7 minutes. After cooling down to room temperature, the slides were treated with blocking solution containing $5 \%$ normal goat serum, $2 \%$ casein, and 3\% BSA for 45 minutes. Anti-TGF- $\beta_{1}$ antibody $(3 \mu \mathrm{g} / \mathrm{ml}$; Santa Cruz Biotechnology, Santa Cruz, CA, USA) or anti- $\alpha_{V} \beta_{6}$ integrin antibody $(5 \mu \mathrm{g} / \mathrm{ml}$; Chemicon International, Temecula, CA, USA $)^{22}$ was applied to the tissue and incubated at $37^{\circ} \mathrm{C}$ for 30 minutes. This TGF- $\beta_{1}$ antibody is not mouse specific and is reactive to human and rat TGF$\beta_{1}$. After a wash with phosphate buffered saline (PBS), biotinylated goat anti-rabbit IgG antibody (for anti-TGF- $\beta_{1}$ antibody) or biotinylated goat anti-mouse IgG antibody (for anti $\alpha_{V} \beta_{6}$ integrin antibody) was applied and the slides were incubated at $37^{\circ} \mathrm{C}$ for 30 minutes. After further washing, avidin-biotin alkaline phosphatase complex was applied and the slides were incubated at $37^{\circ} \mathrm{C}$ for 30 minutes before addition of the substrate solution. Colour development was stopped by rinsing the slides in distilled water. The slides were counterstained with neutral red. Positively immunostained cells were enumerated directly in 10 random high power fields (hpf; magnification $\times 400$ ).

\section{Cytokine production by alveolar macrophages of C57BL/6 mice}

Alveolar macrophages were isolated using previously reported methods with a slight modification..$^{21}$ 37-39 On day 7, alveolar macrophages were obtained by lavaging the lung with sterile PBS containing 1 mM EDTA (Wako). They were centrifuged and resuspended in DMEM (Gibco BRL, Grand Island, NY, USA) supplemented with $10 \%$ FCS, $10 \mathrm{mM}$ HEPES (Gibco BRL), $0.1 \mathrm{mM}$ non-essential amino acid (Gibco BRL), $1 \mathrm{mM}$ sodium pyruvate, $2 \mathrm{mM}$ sodium glutamate (Sigma), $100 \mathrm{U} / \mathrm{ml}$ penicillin (Sigma), $100 \mu \mathrm{g} / \mathrm{ml}$ streptomycin (Sigma), and $5.0 \times 10^{-5} \mathrm{M} 2-\mathrm{ME}$ (Sigma). The cells were plated at a density of $2 \times 10^{6}$ cells $/ \mathrm{ml}$ in tissue culture flasks. After 2 hours at $37^{\circ} \mathrm{C}$, non-adherent cells were removed by rinsing plates twice with medium. After treatment with trypsin/EDTA (Gibco BRL) the cells were centrifuged and cultured in serum-free medium for 24 hours. In another experiment, cells from bleomycin injected mice were cultured in serum-free medium with IL-10 $(12.5,25,50$, 100 , or $200 \mathrm{ng} / \mathrm{ml}$, respectively; Genzyme Techne, Minneapolis, MN, USA) or dexamethasone (0.1 or $1 \mathrm{M}$; Sigma) for 24 hours. Cell numbers were counted with a haemocytometer. Over $90 \%$ of the adherent cells were determined as macrophages based on morphological criteria with Diff-Quick staining. We also confirmed the purity of macrophages by flow cytometry with anti-CDI lb monoclonal antibody (Ml/70; Pharmingen) (data not shown). TGF- $\beta_{1}$
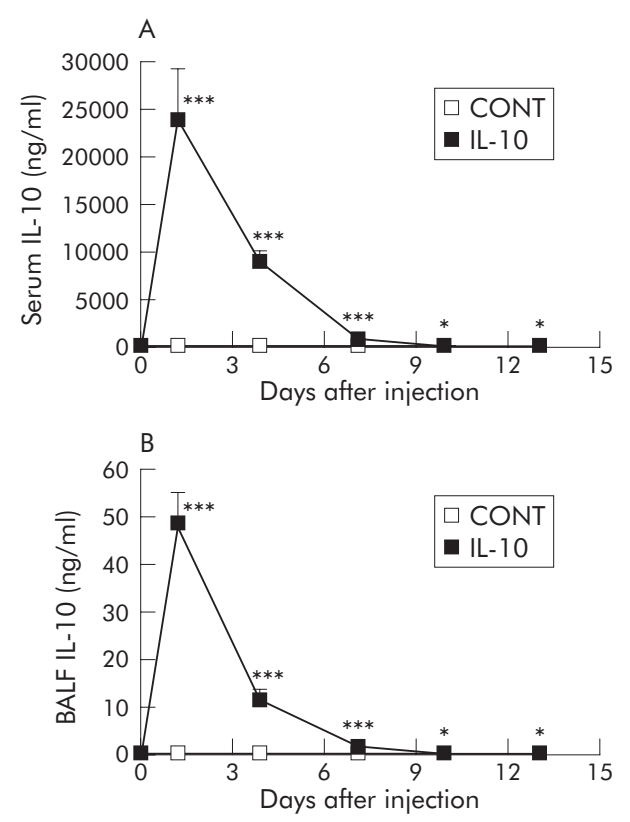

Figure 1 IL-10 expression in (A) serum and (B) BAL fluid after hydrodynamic-based gene therapy by intravenous injection of plasmid DNA in C57BL/6 mice. Mice received an intravenous injection of pCAGGS-IL-10 (100 $\mu \mathrm{g}$; IL-10) or control pCAGGS (100 $\mu \mathrm{g}$; CONT) on day 0 . Concentrations of IL- 10 were measured at the indicated times after the injection using ELISA. Values are presented as mean (SE) for six mice per group. ${ }^{*} p<0.05,{ }^{* * *} p<0.001$ compared with control values.

concentrations in the supernatant were measured before and after activation by acidification using an ELISA kit and data were expressed as pg TGF- $\beta_{1}$ per $10^{5}$ macrophages.

\section{Cytokine production in the macrophage cell line J774. 1}

The macrophage-like cell line J774.1 was obtained from Riken Bioresource Center (Ibaraki, Japan). Cells were stimulated with lipopolysaccharide (LPS; $1 \mu \mathrm{g} / \mathrm{ml}$; Sigma) in serum-free medium in the presence of IL-10 for 24 hours and the TGF- $\beta_{1}$ concentrations in the supernatants were then measured.

\section{Statistical analysis}

The results are presented as mean (SE). Statistical analysis was performed by one way ANOVA followed, when differences were significant, by appropriate post hoc tests using the Tukey test. The Kruskal-Wallis test was used to analyse the inflammation and fibrosis scores because they were discrete values. The Student's t test was used for analysing the differences between the two groups. A p value of $<0.05$ was considered statistically significant. For the primary findings, we showed $95 \%$ confidence intervals (CI) for the mean differences.

\section{RESULTS}

IL- 10 expression in serum and BAL fluid after hydrodynamic-based gene therapy in C57BL/6 mice

The kinetics of IL-10 gene delivery were first examined after the intravenous injection of plasmid DNA in C57BL/6 mice. Samples were collected at specific points in time after the injection of plasmid ( $100 \mu \mathrm{g}$; pCAGGS-IL-10 or control pCAGGS). The temporal pattern of IL-10 protein expression in serum and BAL fluid was confirmed (fig 1 ). The level of IL10 peaked 1 day after the injection and gradually decreased thereafter. On day 13 the IL-10 concentration in the BAL fluid of pCAGGS-IL-10 treated mice was 25.2 (8.6) pg/ml 


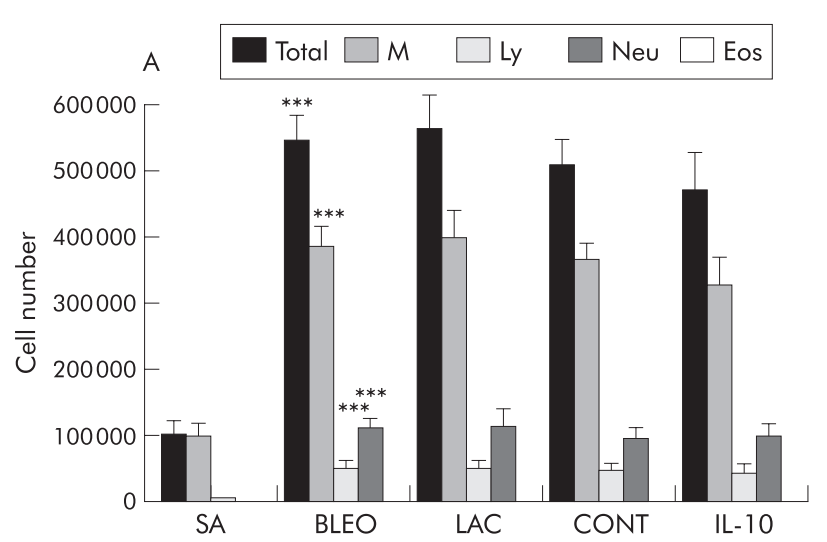

B

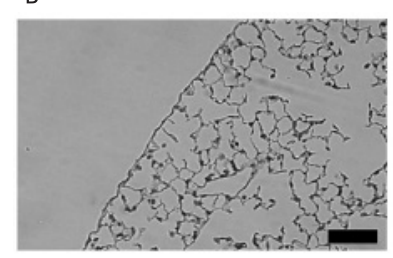

SA

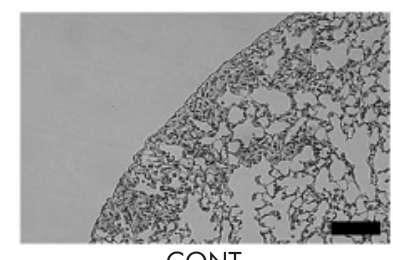

CONT

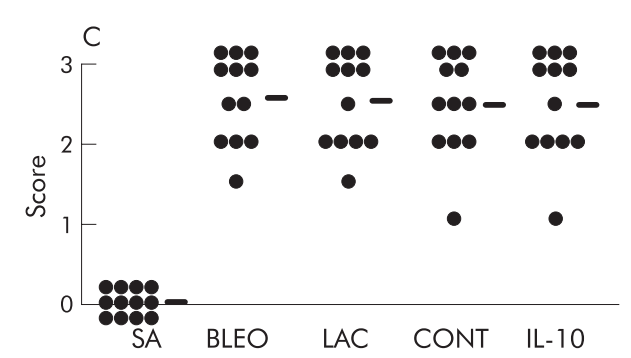

Figure 2 Effect of IL-10 gene delivery on bleomycin (BLEO) induced acute lung inflammation. Mice received an intratracheal injection of bleomycin $(5 \mathrm{mg} / \mathrm{kg})$ on day 0 . Control mice received physiological saline (SA). Some mice received an intravenous injection of pCAGGS-IL10 (100 $\mu \mathrm{g}$; IL-10), control pCAGGS (100 $\mu \mathrm{g}$; CONT), or lactate (LAC) on day 1. On day 7 mice were analysed ( $n=12$ per group). (A) BAL fluid cell analysis: leucocytes were identified based on morphological criteria $(n=12)$. $M$, macrophages; Ly, lymphocytes; Neu, neutrophils; Eos, eosinophils. (B) Histological findings (H\&E) in excised lung; scale bar $100 \mu \mathrm{m}$. (C) Quantitative evaluation of the histological findings by scoring inflammation $(n=12)$. The lesions were defined as described in the Methods section. Horizontal bars indicate mean scores for each group. ${ }^{* *} p<0.001$ compared with the value for saline.

compared with 2.9 (1.1) pg/ml in control pCAGGS treated mice. There was still a significant difference between the two groups $(p<0.05)$. On day 20 IL-10 delivery did not differ between pCAGGS-IL-10 treated mice and control pCAGGS treated mice (data not shown).

\section{Effect of IL- 10 gene delivery on bleomycin induced acute lung inflammation}

Mice received an intratracheal injection of bleomycin or saline on day 0 , followed by an injection of plasmid ( $100 \mu \mathrm{g}$; pCAGGS-IL-10 or control pCAGGS) or lactate alone on day 1. On day 7 the mice were evaluated. Cell numbers in BAL fluid (total cells, macrophages, neutrophils, and lymphocytes) were significantly increased in bleomycin injected mice compared with saline injected mice. IL-10 reduced cell numbers in BAL fluid slightly compared with those in lactate treated (LAC) or control plasmid treated mice (CONT). However, the differences were not significant (fig 2A). Histological examination showed that IL-10 gene delivery did not suppress the infiltration of inflammatory cells into the alveoli and interstitium in the lung (figs $2 \mathrm{~B}$ and $\mathrm{C}$ ).

\section{Effect of IL-10 gene delivery on bleomycin induced pulmonary fibrosis}

Mice received an intratracheal injection of bleomycin on day 0 and an intravenous injection of plasmid on day 1 . The mice were killed on day 14. Bleomycin administration induced focal fibrotic lesions with thickened intra-alveolar septa (fig 3). We first investigated the optimal dose of IL-10 plasmid. In vivo IL-10 gene delivery suppressed the hydroxyproline level in a plasmid dose dependent manner and $100 \mu \mathrm{g}$ of pCAGGS-IL-10 per mouse was the optimal dose (fig 3A). Based on this finding, we used $100 \mu \mathrm{g}$ of IL-10 plasmid for the following experiment. IL-10 treatment strongly suppressed fibrotic lesions (fig 3B); Azan staining confirmed that IL-10 treatment suppressed collagen deposition in the lung (fig 3C). A quantitative evaluation of the histological findings made by scoring fibrotic changes showed that IL-10 treatment significantly suppressed the intensity of pulmonary fibrosis (fig 3D). In vivo IL-10 delivery suppressed the increase in hydroxyproline level in the lung compared with control plasmid treated mice (fig 3E; saline, 769 (32) $\mu \mathrm{g} / \mathrm{g}$ tissue; bleomycin, 1184 (102) $\mu \mathrm{g} / \mathrm{g}$ tissue; lactate, 1357 (120) $\mu \mathrm{g} / \mathrm{g}$ tissue; control, 1064 (66) $\mu \mathrm{g} / \mathrm{g}$ tissue; IL-10, 725 (76) $\mu \mathrm{g} / \mathrm{g}$ tissue; control $v$ IL-10, $\mathrm{p}<0.05$, 95\% CI 1.22 to 676.69$)$. Moreover, IL-10 gene delivery suppressed the concentrations of both the total form of TGF- $\beta_{1}$ (fig 3F; saline, 14.9 (3.2) pg/ml; bleomycin, 86.6 (7.9) pg/ml; lactate, 97.7 (6.6) pg/ml; control, 82.1 (5.7) pg/ml; IL-10, 58.7 (4.6) $\mathrm{pg} / \mathrm{ml}$; control $v$ IL-10, $\mathrm{p}<0.05,95 \%$ CI 0.15 to 46.64 ) and its active form (fig 3G; saline, 1.4 (1.0) pg/ml; bleomycin, 18.7 (1.4) pg/ml; lactate, 18.6 (1.7) pg/ml; control, 19.0 (1.7) $\mathrm{pg} / \mathrm{ml} ;$ IL-10, 11.1 (2.3) pg/ml; control $v$ IL-10, $\mathrm{p}<0.05,95 \%$ CI 1.22 to 14.57 ) in the BAL fluid, which is the most prominent isoform of TGF- $\beta$ detected during bleomycin induced injury. ${ }^{37}$ These results suggest that in vivo IL-10 gene delivery suppresses the development of pulmonary fibrosis induced by bleomycin. In a preliminary study we delivered the IL-10 gene 3 days before injecting bleomycin and examined the effect on inflammation and fibrosis. Bleomycin induced inflammation and fibrosis were both significantly suppressed (data not shown), which was consistent with a previous report. ${ }^{30}$

Effect of IL-10 gene delivery on the expression of TGF$\beta_{1}$ and $\alpha_{V} \beta_{6}$ integrin in the lung

The expression of TGF- $\beta_{1}$ in the lung was examined using immunohistochemistry. In bleomycin injected mice TGF- $\beta_{1}$ was detected mainly in alveolar macrophages, epithelial cells, and the interstitium (fig 4A). This finding was consistent with a previous study on human IPF. ${ }^{17}$ In bleomycin injected mice treated with IL-10, TGF- $\beta_{1}$ expression in the lung, especially in macrophages, was decreased (saline $1.7(0.3)$ / hpf; bleomycin, 16.6 (1.4)/hpf; lactate, 16.7 (1.5)/hpf; control, $13.6(0.8) / \mathrm{hpf} ;$ IL-10, $8.7(0.8) / \mathrm{hpf})$. We then examined the expression of $\alpha_{v} \beta_{6}$ integrin on epithelial cells. In lactate treated mice and control pCAGGS treated mice the expression of $\alpha_{\mathrm{v}} \beta_{6}$ integrin was upregulated in lung epithelial cells by bleomycin injection compared with saline injected mice. IL-10 gene delivery suppressed this expression (fig 4B; saline, 


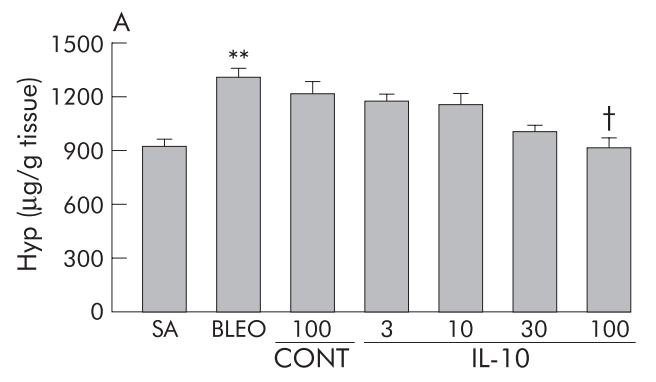

B

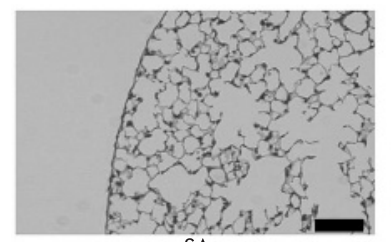

SA

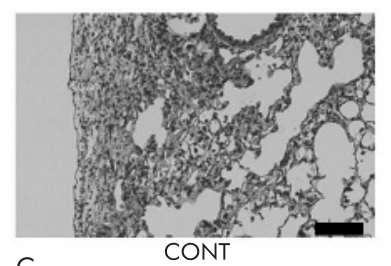

C

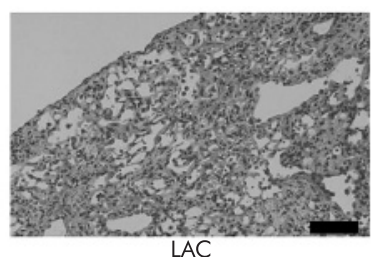

LAC

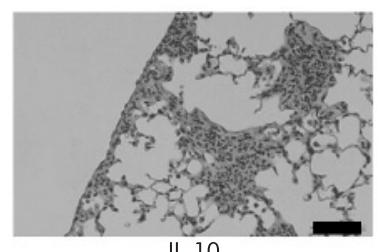

IL-10
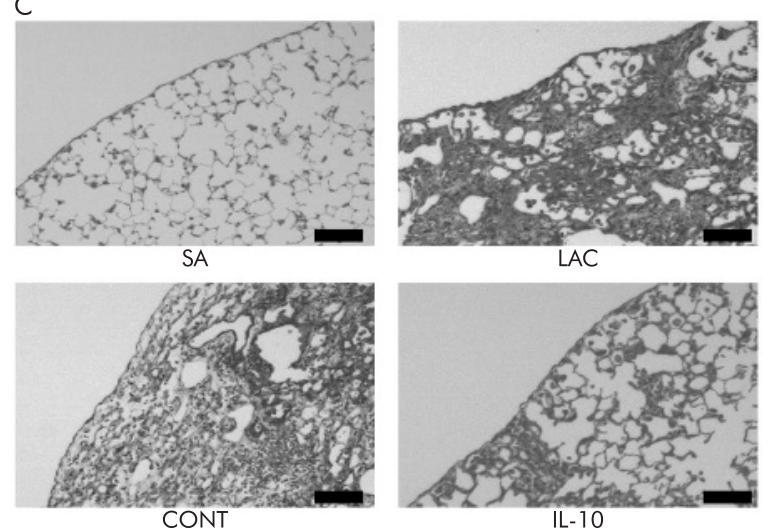

2.

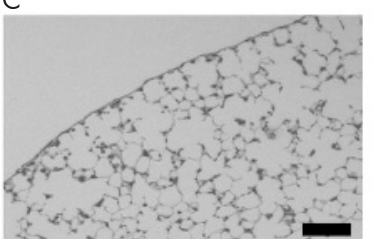

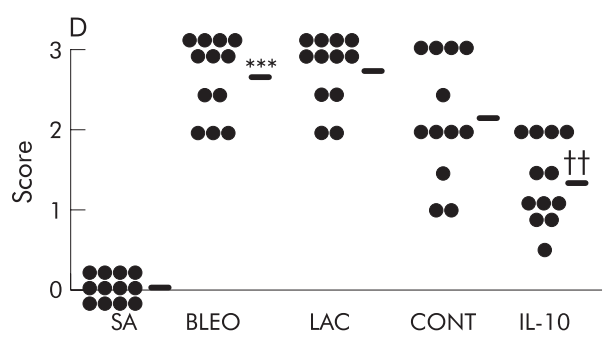
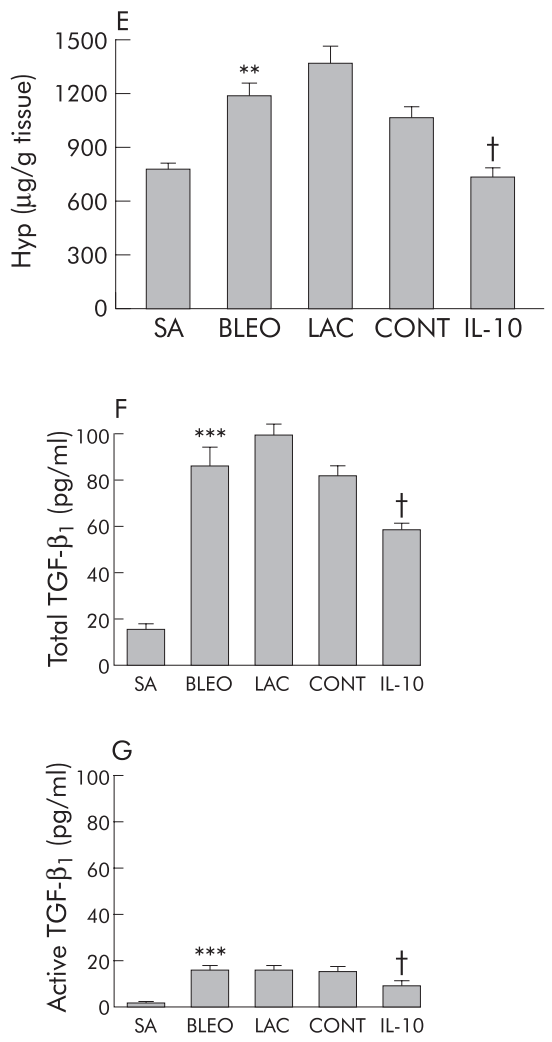

Figure 3 Effect of IL-10 gene delivery on bleomycin (BLEO) induced pulmonary fibrosis. Mice were given an intratracheal injection of bleomycin $(5 \mathrm{mg} / \mathrm{kg})$ on day 0 ; control mice were given physiological saline (SA). On day 1 some mice received an intravenous injection of pCAGGS-IL-10 $(100 \mu \mathrm{g} ; \mathrm{IL}-10)$, some were given control pCAGGS $(100 \mu \mathrm{g} ; \mathrm{CONT})$, and the rest were given lactate (LAC). On day 14 the mice were analysed ( $\mathrm{n}=12$ per group). (A) Dose dependent effect of IL-10 producing plasmid on the development of pulmonary fibrosis. Lungs were excised and a hydroxyproline assay was performed $(n=12)$. (B) Histological findings (stain: H\&E); scale bar $100 \mu \mathrm{m}$. (C) Azan staining; scale bar $100 \mu \mathrm{m}$. (D) Quantitative evaluation of the histological findings by scoring fibrotic changes $(n=12)$. The lesions were defined as described in the Methods section. Horizontal bars indicate mean scores for each group. (E) Hydroxyproline assay on excised lung samples $(n=12)$. (F) Concentrations of total TGF- $\beta_{1}$ in BAL fluid assayed after activation by acidification using an ELISA kit $(n=12)$. (G) Concentrations of active form of TGF- $\beta_{1}$ in BAL fluid assayed before acidification $(n=12) .{ }^{* *} p<0.01$ and ${ }^{* * *} p<0.001 \vee S A ; p p<0.05$ and $+\uparrow p<0.01 \vee$ CONT.

$0.5(0.2) / \mathrm{hpf} ;$ bleomycin, $3.9(0.5) / \mathrm{hpf} ;$ lactate, $4.6(0.6) / \mathrm{hpf}$; control, $3.5(0.5) / \mathrm{hpf}$; IL-10, $2.2(0.5) / \mathrm{hpf})$.

\section{Effect of in vivo IL-10 gene delivery on TGF- $\beta_{1}$ production by alveolar macrophages}

We then confirmed the effect of IL-10 using explanted alveolar macrophages ex vivo (fig 5). Alveolar macrophages explanted from bleomycin injected mice spontaneously produced both total and active forms of TGF- $\beta_{1}$, and IL-10 gene delivery suppressed their production (fig $5 \mathrm{~A}$; total form: saline 8.6 (1.3) pg/ml; bleomycin, 51.8 (6.5) pg/ml; lactate, 48.6 (6.7) pg/ml; control, 54.8 (5.9) pg/ml; IL-10, 33.4 (2.3) $\mathrm{pg} / \mathrm{ml}$; control $v$ IL-10, $\mathrm{p}<0.05,95 \%$ CI 0.75 to 41.89 ; fig 5B; active form: saline, $2.1(0.8) \mathrm{pg} / \mathrm{ml}$; bleomycin, 15.5 (0.9) pg/ml; lactate, 15.0 (1.9) pg/ml; control, 13.6 (1.1) pg/ ml; IL-10, $8.9(0.4) \mathrm{pg} / \mathrm{ml}$; control $v$ IL-10, p<0.05, 95\% CI 0.13 to 9.17$)$. Moreover, production of both total and active forms of TGF- $\beta_{1}$ by explanted alveolar macrophages obtained from IL-10 deficient mice with bleomycin injection was upregulated compared with wild-type mice (fig 5C; total form: wild-type, 48.0 (4.8) pg/ml; IL-10 ${ }^{-/-}, 63.9$ (4.8) pg/ml; $\mathrm{p}<0.05,95 \%$ CI 1.29 to 30.44; fig 5D; active form: wild-type, 17.3 (1.5) pg/ml; IL- $10^{-/-}, 25.0$ (2.2) pg/ml; p<0.05, 95\% CI 1.98 to 13.42 ). These results indicate that IL-10 suppressed the production of TGF- $\beta_{1}$ by alveolar macrophages.

In another experiment we examined the production of endogenous IL-10 by alveolar macrophages. IL-10 production by explanted alveolar macrophages was slightly increased by bleomycin treatment compared with saline injection (data not shown). IL-10 gene delivery induced a slight additional 


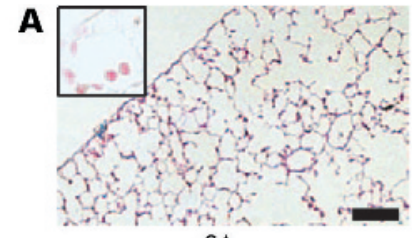

SA

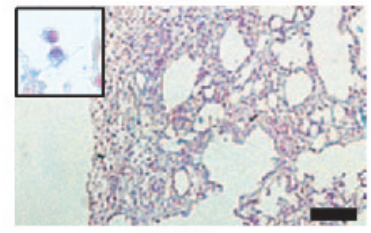

CONT

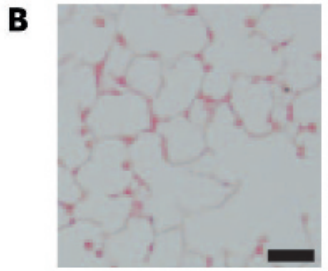

SA

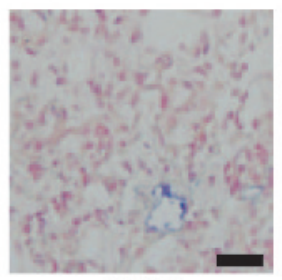

CONT

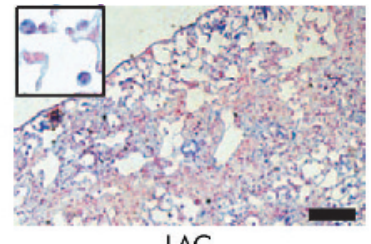

LAC

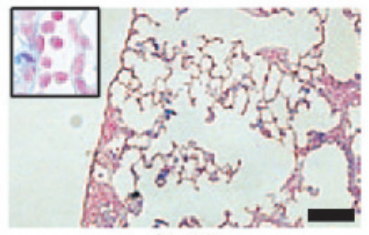

IL-10

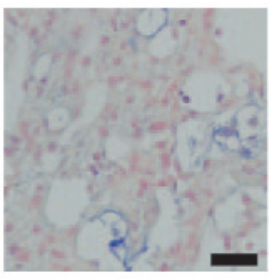

LAC

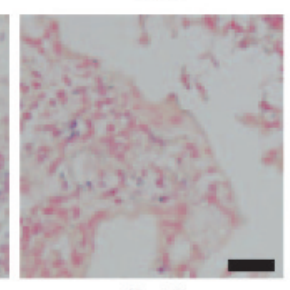

IL-10

Figure 4 Effect of IL-10 gene delivery on the expression of TGF- $\beta_{1}$ and $\alpha_{V} \beta_{6}$ integrin in the lung. (A) Immunohistochemistry for TGF- $\beta_{1}$. Mice were treated as described in fig 3. On day 14 the lungs were excised and stained for TGF- $\beta_{1}$ (blue). Counterstaining was performed with neutral red. Scale bar $100 \mu \mathrm{m}$. Insertion: staining for TGF- $\beta_{1}$ in alveolar macrophages (blue). (B) Immunohistochemistry for $\alpha_{v} \beta_{6}$ integrin. On day 14 the lungs were excised and stained for $\alpha_{v} \beta_{6}$ integrin (blue). Counterstaining was performed with neutral red. Scale bar $40 \mu \mathrm{m}$. SA, saline; LAC, lactate; CONT, control.

increase in endogenous IL-10 production, although it was not significantly different from that of control plasmid treated mice (data not shown).

\section{Effect of IL- 10 on TGF- $\beta_{1}$ production by activated alveolar macrophages}

We then examined the direct effect of IL-10 on TGF- $\beta_{1}$ production in alveolar macrophages activated by instillation of bleomycin. Alveolar macrophages explanted from the bleomycin injected mice were cultured in the presence or absence of IL-10 and TGF- $\beta_{1}$ production was examined. As shown in fig 6A and $\mathrm{B}$, alveolar macrophages from bleomycin injected mice produced more total and active TGF- $\beta_{1}$ than macrophages from saline injected mice. Although the production of total amounts of TGF- $\beta_{1}$ seemed to increase

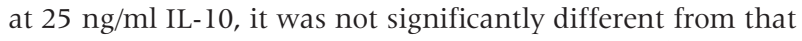
without IL-10. IL-10 significantly suppressed TGF- $\beta_{1}$ production at a high concentration (total form: bleomycin, 56.8 (2.2) pg/ml; IL-10 (200 ng/ml), 36.1 (1.9) pg/ml; bleomycin $v$ IL-10 (200 ng/ml), p<0.05, 95\% CI 0.85 to 40.53; active form: bleomycin, 18.8 (1.7) pg/ml; IL-10 (100 ng/ml), 9.1 (1.2) pg/ $\mathrm{ml}$; IL-10 (200 ng/ml), $9.6(0.6) \mathrm{pg} / \mathrm{ml}$; bleomycin $v$ IL-10 $(100 \mathrm{ng} / \mathrm{ml}), \mathrm{p}<0.05,95 \%$ CI 0.92 to 18.55 ; bleomycin $v$ IL- 10 (200 ng/ml), p<0.05, 95\% CI 0.40 to 18.03$)$. On the other hand, dexamethasone did not suppress TGF- $\beta_{1}$ production,
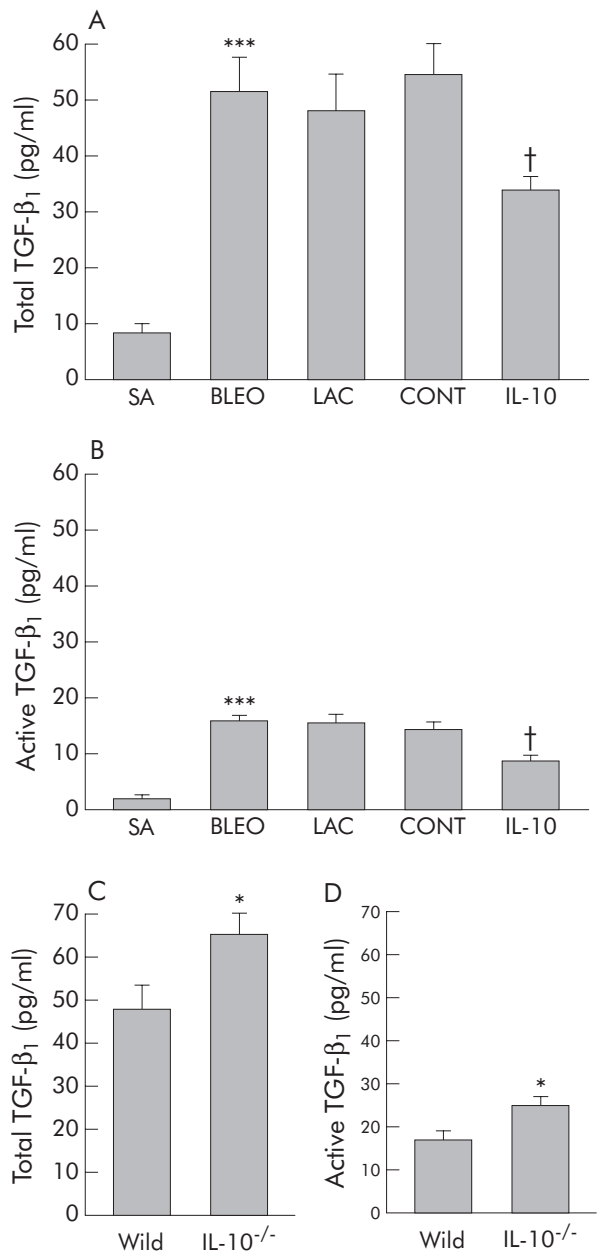

Figure 5 Effect of IL-10 gene delivery on TGF- $\beta_{1}$ production in explanted alveolar macrophages. Mice received an intratracheal injection of bleomycin (BLEO) on day 0 and an intravenous injection of plasmid on day 1 . On day 7 BAL was performed. Cells were plated in tissue culture flasks and after 2 hours at $37^{\circ} \mathrm{C}$ non-adherent cells were removed. After trypsin/EDTA treatment the cells were resuspended and cultured in serum-free medium for 24 hours ( $n=8$ per group). (A) Concentration of total TGF- $\beta_{1}$ in supernatants measured after activation by acidification using an ELISA kit expressed as pg TGF- $\beta_{1}$ per $10^{5}$ macrophages $(n=8)$. (B) Concentration of active form of TGF- $\beta_{1}$ in supernatants measured before acidification $(n=8)$. ${ }^{* * *} p<0.001 v$ saline (SA); $\uparrow p<0.05 v$ control (CONT). (C, D) Effect of deletion of the IL-10 gene on TGF- $\beta_{1}$ production in explanted alveolar macrophages. IL-10 deficient mice (IL-10-1-) or wild-type mice (wild) received bleomycin. On day 7 BAL was performed. Alveolar macrophages were treated as described in $A$ and $B$ ( $n=8$ per group). (C) Concentrations of total TGF$\beta_{1}$ expressed as pg TGF- $\beta_{1}$ per $10^{5}$ macrophages $(n=8)$. (D) Concentrations of active form of TGF- $\beta_{1}(n=8)$. ${ }^{*} p<0.05 v$ wild-type mice.

consistent with a previous report. ${ }^{37}$ These results suggest that IL-10 could, at least in part, directly suppress the production of TGF- $\beta_{1}$ by activated alveolar macrophages.

In another experiment we stimulated the macrophage cell line J774.1 with bleomycin, but the production of TGF- $\beta_{1}$ was not affected (data not shown). Instead, we stimulated J774.1 cells with lipopolysccharide (LPS) which upregulated TGF- $\beta_{1}$ production (fig 6C). With LPS stimulation, IL-10 also suppressed the production at a concentration as low as $25 \mathrm{ng} / \mathrm{ml}$ (LPS, 125.8 (15.5) pg/ml; IL-10 (25 ng/ml), 86.9 (4.4) $\mathrm{pg} / \mathrm{ml} ; \quad$ IL-10 (50 ng/ml), $85.6 \quad$ (6.2) pg/ml; IL-10 $(100 \mathrm{ng} / \mathrm{ml}), 88.2 \quad(7.3) \mathrm{pg} / \mathrm{ml} ;$ LPS $v$ IL-10 $(25 \mathrm{ng} / \mathrm{ml})$, $\mathrm{p}<0.05$, 95\% CI 3.94 to 73.74 ; LPS $v$ IL-10 $(50 \mathrm{ng} / \mathrm{ml})$, $\mathrm{p}<0.05$, 95\% CI 5.27 to 75.07 ; LPS $v$ IL- $10(100 \mathrm{ng} / \mathrm{ml})$, 

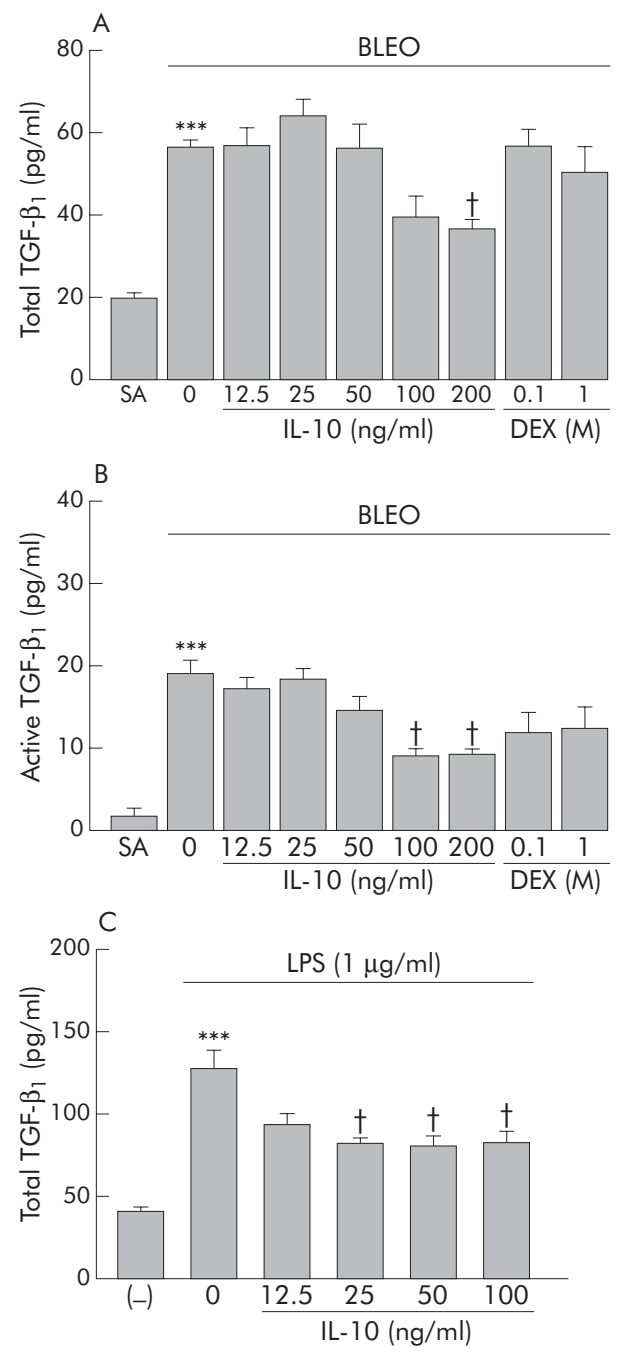

Figure 6 Effect of IL-10 on production of TGF- $\beta_{1}$ by activated alveolar macrophages. Mice received an intratracheal injection of bleomycin (BLEO) or saline (SA) on day 0 . On day $7 \mathrm{BAL}$ was performed. The cells were plated at a density of $2 \times 10^{6} \mathrm{cell} / \mathrm{s} / \mathrm{ml}$ in tissue culture flasks. After 2 hours at $37^{\circ} \mathrm{C}$, non-adherent cells were removed. Then, after trypsin/ EDTA treatment, macrophages from bleomycin injected mice were cultured with IL-10 or dexamethasone (DEX) in serum-free medium for 24 hours ( $n=8$ per group). (A) Concentrations of total TGF- $\beta_{1}$ in supernatants expressed as pg TGF- $\beta_{1}$ per $10^{5}$ macrophages $(n=8)$. (B) Concentrations of active form of TGF- $\beta_{1}$ in supernatants $(n=8)$. $* * * p<0.001 \vee$ SA injected mice; $\uparrow p<0.05 v$ bleomycin injected mice without IL-10. (C) Effect of IL-10 on TGF- $\beta_{1}$ protein production induced by lipopolysaccharide (LPS) in a macrophage cell line. J774.1 cells were incubated with LPS for 24 hours in the presence or absence of IL-10. TGF- $\beta_{1}$ concentrations in the supernatants were measured after activation by acidification using an ELISA kit $(n=8) .{ }^{* * *} p<0.001 v$ macrohpages without LPS stimulation; $\uparrow p<0.05 v$ macrophages stimulated with LPS without IL-10.

$\mathrm{p}<0.05,95 \%$ CI 2.69 to 72.48$)$. We also confirmed that stimulation with LPS upregulated the expression of TGF- $\beta_{1}$ mRNA of J774.1 cells and IL-10 suppressed their expression (data not shown).

\section{Effect of IL-10 gene delivery in the chronic fibrosing process}

Finally we examined whether IL-10 gene delivery could suppress the chronic fibrosing process even if delivered when pulmonary fibrosis had developed. As lung fibrosis had developed on day 14 (fig 3), gene delivery of IL-10 was started at this time and was repeated on days 19 and 24
A

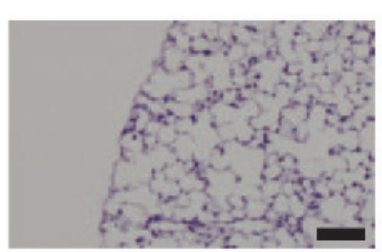

SA

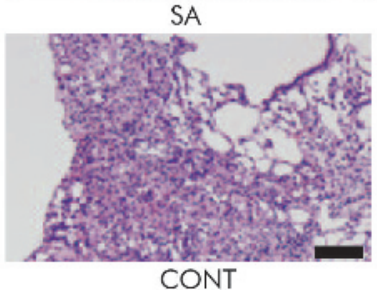

B

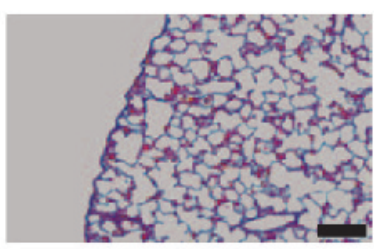

SA

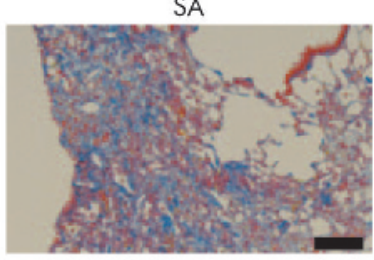

CONT

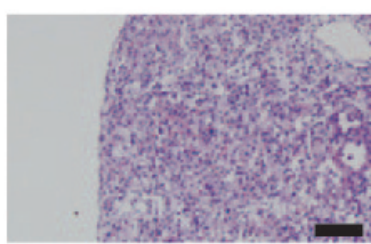

LAC

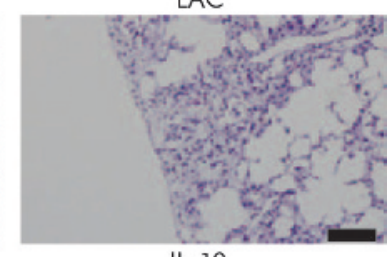

IL-10

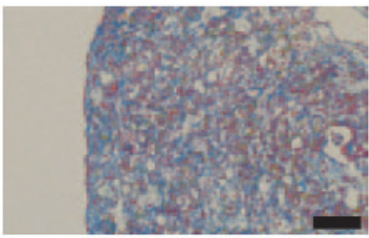

LAC

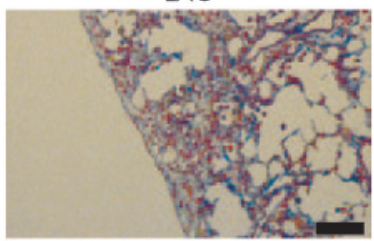

IL-10
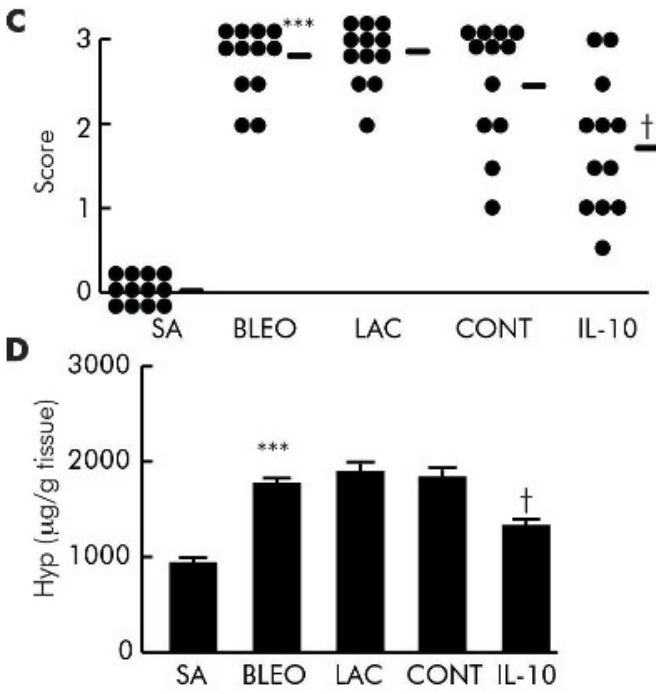

Figure 7 Effect of IL-10 gene delivery on pulmonary fibrosis after the development of fibrosis. Mice received an intratracheal injection of bleomycin (BLEO) or saline (SA) on day 0 . Some mice received an intravenous injection of pCAGGS-IL-10 (IL-10), control pCAGGS (CONT), or lactate (LAC) on days 14, 19, and 24. On day 28 the mice were killed ( $n=12$ per group). (A) Histological findings (stain H\&E) on excised lungs; scale bar $100 \mu \mathrm{m}$. (B) Azan staining. Scale bar $100 \mu \mathrm{m}$. (C) Quantitative evaluation of the histological findings by scoring fibrotic change $(n=12)$. Horizontal bars indicate means of each group. (D) Hydroxyproline assay $(n=12)$ performed on day 28 in excised lungs. ${ }_{* * *} p<0.001 \vee S A ;+p<0.05 \vee$ CONT.

during the further development of fibrosis. On day 28 the mice were evaluated. IL-10 gene delivery suppressed pulmonary fibrosis which was assessed by histological findings (fig 7A). The result from Azan staining showed that collagen 
deposition in the lung was attenuated by IL-10 treatment (fig 7B). The effect of IL-10 was also confirmed by histological scoring (fig 7C) and by hydroxyproline assay (fig 7D; saline, 962 (75) $\mu \mathrm{g} / \mathrm{g}$ tissue; bleomycin, $1740(80) \mu \mathrm{g} /$ $\mathrm{g}$ tissue; lactate, 1834 (131) $\mu \mathrm{g} / \mathrm{g}$ tissue; control, 1791 (128) $\mu \mathrm{g} / \mathrm{g}$ tissue; IL-10, 1365 (81) $\mu \mathrm{g} / \mathrm{g}$ tissue; control $v$ IL$10, \mathrm{p}<0.05,95 \%$ CI 19.27 to 832.29 ). These results showed that IL-10 could suppress the fibrosing process itself even if delivered in the fibrosing phase.

\section{DISCUSSION}

The results of this study clearly show that in vivo IL-10 gene delivery, even when delivered during the chronic phase, suppresses the development of pulmonary fibrosis. They also indicate that alveolar macrophages are an important source of TGF- $\beta_{1}$ and that IL-10 strongly suppresses the production of both total and active forms of TGF- $\beta_{1}$ from alveolar macrophages, thus attenuating the intensity of the fibrosis.

In a previous study Arai and co-workers ${ }^{30}$ reported that IL10 gene delivery before bleomycin administration suppresses pulmonary fibrosis, probably by inhibiting the initial inflammatory process which is induced by bleomycin injection. However, the effect of gene delivery after the insult was not clarified in their report, which hinders the use of gene therapy for human IPF patients. In contrast, we have clearly shown that our gene delivery system was effective even after fibrosis had already developed (fig 7). The discrepancy in the results is partly due to a difference in the gene delivery system. Arai and co-workers used an HVJ liposome system while we used a hydrodynamic based gene delivery system. The latter system can achieve a higher concentration of IL-10 protein in the lung (fig l) than the former system. It is considered that, in our study, a certain amount of IL-10 delivered into the lung suppressed the fibrosis even if it was delivered after the insult. We have used the same system in another study in which we showed that IL-10 gene delivery is also effective in regulating allergic airway inflammation. ${ }^{33}$ Although the hydrodynamic based gene delivery system cannot be directly applied to humans, these findings strongly indicate that, if IL-10 could be delivered selectively and effectively in the lung, it could be a very effective option for the treatment of human lung diseases. Progress in the site specific delivery of IL-10 must therefore be achieved for future clinical applications.

Among many profibrotic cytokines, TGF- $\beta$ is a key growth factor that directly promotes the synthesis of collagen by many kinds of fibroblasts including those of the lung, and thus plays a key role in the development of fibrosis. ${ }^{16}$ Therapeutic trials to regulate TGF- $\beta$ function in experimental pulmonary fibrosis to date have focused on changes in TGF- $\beta$ signal transduction. ${ }^{9-11}$ On the other hand, attempts to suppress TGF- $\beta$ production or activation itself have rarely been successful. Khalil and co-workers ${ }^{37}$ found that dexamethasone did not suppress the production of TGF- $\beta_{1}$ by alveolar macrophages from bleomycin treated rats, and we obtained the same result (fig 6).

The relation between IL-10 and TGF- $\beta$ has been unclear. In this study we show, for the first time, that IL-10, a cytokine with various immunoregulatory effects, suppresses TGF- $\beta_{1}$ production in the lung (figs 3-6). We have confirmed that IL10 suppresses the production of TGF- $\beta_{1}$ by stimulated alveolar macrophages both in vitro and in vivo (figs 5 and 6 ). We also found that IL-10 suppresses the expression of TGF- $\beta_{1}$ mRNA in LPS stimulated macrophage-like cell line J774.1 (data not shown), which suggests that IL-10 could suppress the mRNA expression of TGF- $\beta_{1}$ and thus suppress the production of TGF$\beta_{1}$ protein. Furthermore, the decrease in TGF- $\beta_{1}$ production by alveolar macrophages correlates with the suppression of fibrosis (figs 3 and 4). These results strongly suggest that inhibition of TGF- $\beta_{1}$ production from alveolar macrophages by IL-10 could lead to the suppression of fibrosis. However, the effect of IL-10 on cells other than macrophages such as epithelial cells or fibroblasts should be considered, because suppression of TGF- $\beta_{1}$ production from alveolar macrophages by IL-10 was not so strong (figs 5 and 6). For example, Arai and co-workers $^{30}$ reported that IL-10 reduced constitutive and TGF$\beta$ induced type I collagen mRNA expression in fibroblasts in vitro; this effect on fibroblasts might play a part in the suppression of fibrosis by IL-10.

The mechanisms underlying the production, activation, and signal transduction of TGF- $\beta$, especially in the lung, are complicated. ${ }^{5}{ }^{16}$ Although our results indicate that IL-10 apparently suppressed TGF- $\beta_{1}$ in the lung, the mechanism of the suppression needs to be further elucidated. For example, results from the in vitro study suggest that IL-10 had a direct effect on TGF- $\beta_{1}$ production from macrophages at a high concentration (fig 6). Judging from the time course study (fig 1), our gene delivery could produce a sufficiently high concentration in the serum. However, it could not produce a high concentration of IL-10 in the lung, although the values in the BAL fluid may underestimate the true concentration of IL-10 in the alveolar lining fluid. Indirect mechanisms of IL10 to downregulate TGF- $\beta_{1}$ production through other cytokines affecting TGF- $\beta_{1}$ in the lung may therefore also play an important role. We also found that IL-10 treatment attenuated the expression of $\alpha_{V} \beta_{6}$ integrin on epithelial cells (fig 4B). This finding suggests that downregulation of $\alpha_{V} \beta_{6}$ integrin expression might be one of the mechanisms by which IL- 10 suppresses TGF- $\beta$ activation. On the other hand, IL-10 might suppress the $\alpha_{\mathrm{V}} \beta_{6}$ integrin expression on epithelial cells indirectly by suppressing the production of TGF- $\beta$ itself which upregulates the expression of $\alpha_{V} \beta_{6}$ integrin. ${ }^{40}$ Furthermore, thrombospondin- $\mathrm{l}^{20}$ and plasmin ${ }^{21}$ also play an important part in the activation of TGF- $\beta$. The effects of IL-10 on these molecules involved in proteolytic cleavage and activation of TGF- $\beta$ should therefore also be investigated further.

Our results showed that not all the IL- 10 treated mice had a reduced fibrosis score. The response to bleomycin varies considerably between individuals, and this might be the reason why the fibrosis score was not reduced in all the mice that received IL-10 expressing plasmid. We therefore used 12 mice for each in vivo experiment to confirm the reliability of the result and found that IL-10 gene delivery significantly suppressed the development of pulmonary fibrosis.

In summary, IL-10 suppresses the production and activation of TGF- $\beta$ in the lung, thus attenuating pulmonary fibrosis. IL-10 gene delivery could become a novel strategy for treating pulmonary fibrosis. Progress in the site specific delivery of IL-10 and an understanding of the mechanism of TGF- $\beta$ activation must be achieved for future clinical applications.

\section{ACKNOWLEDGEMENTS}

The authors thank Professor Kohei Miyazono (Department of Molecular Pathology, Graduate School of Medicine, University of Tokyo, Tokyo, Japan) for critical review of this study, and I Makino and K Kurosaki for technical assistance.

\section{Authors' affiliations \\ K Nakagome, M Dohi, K Okunishi, R Tanaka, K Yamamoto, Pulmonary Division, Department of Allergy and Rheumatology, Graduate School of Medicine, University of Tokyo, Tokyo, Japan \\ J Miyazaki, Division of Stem Cell Regulation Research, Osaka University Graduate School of Medicine, Osaka, Japan}

Funding: Grant-in-aid 13670592 from the Ministry of Health, Welfare, and Labor of Japan.

Competing interests: none. 


\section{REFERENCES}

1 Gross TJ, Hunninghake GW. Idiopathic pulmonary fibrosis. N Engl J Med 2001;345:517-25.

2 King TE Jr, Schwarz MI, Brown K, et al. Idiopathic pulmonary fibrosis: relationship between histopathologic features and mortality. Am J Respir Crit Care Med 2001;164:1025-32.

3 Collard HR, Ryu JH, Douglas WW, et al. Combined corticosteroid and cyclophosphamide therapy does not alter survival in idiopathic pulmonary fibrosis. Chest 2004;125:2169-74.

4 Thannickal VJ, Toews GB, White ES, et al. Mechanisms of pulmonary fibrosis. Annu Rev Med 2004:55:395-417.

5 Chapman HA. Disorders of lung matrix remodeling. J Clin Invest 2004; 113:148-57.

6 Selman M, Thannickal VJ, Pardo A, et al. Idiopathic pulmonary fibrosis: pathogenesis and therapeutic approaches. Drugs 2004;64:405-30.

7 Raghu G, Brown KK, Bradford WZ, et al. A placebo-controlled trial of interferon gamma- $1 \mathrm{~b}$ in patients with idiopathic pulmonary fibrosis. N Engl J Med 2004;350:125-33.

8 Raghu G, Johnson WC, Lockhart D, et al. Treatment of idiopathic pulmonary fibrosis with a new antifibrotic agent, pirfenidone: results of a prospective, open-label phase II study. Am J Respir Crit Care Med 1999;159:1061-9.

9 Giri SN, Hyde DM, Hollinger MA. Effect of antibody to transforming growth factor $\beta$ on bleomycin induced accumulation of lung collagen in mice. Thorax 1993;48:959-66.

10 Wang Q, Wang Y, Hyde DM, et al. Reduction of bleomycin induced lung fibrosis by transforming growth factor $\beta$ soluble receptor in hamsters. Thorax 1999;54:805-12.

11 Nakao A, Fujii M, Matsumura R, et al. Transient gene transfer and expression of Smad7 prevents bleomycin-induced lung fibrosis in mice. J Clin Invest 1999;104:5-11.

12 Dohi M, Hasegawa T, Yamamoto K, et al. Hepatocyte growth factor attenuates collagen accumulation in a murine model of pulmonary fibrosis. Am J Respir Crit Care Med 2000;162:2302-7.

13 Chua F, Gauldie J, Laurent GJ. Pulmonary fibrosis: searching for model answers. Am J Respir Cell Mol Biol 2005;33:9-13.

14 Borzone G, Moreno R, Urrea R, et al. Bleomycin-induced chronic lung damage does not resemble human idiopathic pulmonary fibrosis. Am J Respir Crit Care Med 2001;163:1648-53.

15 Gorelik L, Flavell RA. Transforming growth factor- $\beta$ in T-cell biology. Nat Rev Immunol 2002;2:46-53

16 Bartram U, Speer CP. The role of transforming growth factor $\beta$ in lung development and disease. Chest 2004; 125:754-65.

17 Broekelmann TJ, Limper AH, Colby TV, et al. Transforming growth factor $\beta_{1}$ is present at sites of extracellular matrix gene expression in human pulmonary fibrosis. Proc Natl Acad Sci USA 1991;88:6642-6.

18 Kaminski N, Allard JD, Pittet JF, et al. Global analysis of gene expression in pulmonary fibrosis reveals distinct programs regulating lung inflammation and fibrosis. Proc Natl Acad Sci USA 2000;97:1778-83.

19 Munger JS, Huang X, Kawakatsu $H$, et al. The integrin $\alpha v \beta 6$ binds and activates latent TGF $\beta_{1}$ : a mechanism for regulating pulmonary inflammation and fibrosis. Cell 1999:96:319-28.

20 Crawford SE, Stellmach V, Murphy-Ullrich JE, et al. Thrombospondin-1 is a major activator of TGF- $\beta_{1}$ in vivo. Cell 1998;93:1159-70.

21 Khalil N, Corne S, Whitman $C$, et al. Plasmin regulates the activation of cellassociated latent TGF- $\beta_{1}$ secreted by rat alveolar macrophages after in vivo bleomycin injury. Am J Respir Cell Mol Biol 1996;15:252-9.
22 Cho JY, Miller M, Baek KJ, et al. Inhibition of airway remodeling in IL-5deficient mice. J Clin Invest 2004;113:551-60.

23 Moore KW, de Waal Malefyt R, Coffman RL, et al. Interleukin-10 and the interleukin-10 receptor. Annu Rev Immunol 2001;19:683-765.

24 van Deventer SJ, Elson CO, Fedorak RN. Multiple doses of intravenous interleukin 10 in steroid-refractory Crohn's disease. Crohn's Disease Study Group. Gastroenterology 1997; 113:383-9.

25 Asadullah K, Sterry W, Stephanek K, et al. IL-10 is a key cytokine in psoriasis. Proof of principle by IL-10 therapy: a new therapeutic approach, J Clin Invest 1998;101:783-94.

26 Freeburn RW, Armstrong L, Millar AB. Cultured alveolar macrophages from patients with idiopathic pulmonary fibrosis (IPF) show dysregulation of ipopolysaccharide-induced tumor necrosis factor- $\alpha$ (TNF- $\alpha$ ) and interleukin10 (IL-10) inductions. Eur Cytokine Netw 2005;16:5-16.

27 Martinez JA, King TE Jr, Brown K, et al. Increased expression of the interleukin-10 gene by alveolar macrophages in interstitial lung disease. Am J Physiol 1997;273:L676-83.

28 Kradin RL, Sakamoto H, Jain F, et al. IL-10 inhibits inflammation but does not affect fibrosis in the pulmonary response to bleomycin. Exp Mol Pathol 2004;76:205-11.

29 Kitani A, Fuss I, Nakamura K, et al. Transforming growth factor (TGF)- $\beta_{1}$ producing regulatory $T$ cells induce Smad-mediated interleukin 10 secretion that facilitates coordinated immunoregulatory activity and amelioration of TGF- $\beta_{1}$-mediated fibrosis. J Exp Med 2003;198:1179-88.

30 Arai T, Abe K, Matsuoka H, et al. Introduction of the interleukin-10 gene into mice inhibited bleomycin-induced lung injury in vivo. Am J Physiol Lung Cell Mol Physiol 2000;278:L914-22.

31 Jiang J, Yamato E, Miyazaki J. Intravenous delivery of naked plasmid DNA for in vivo cytokine expression. Biochem Biophys Res Commun 2001;289: 1088-92.

32 Niwa H, Yamamura K, Miyazaki J. Efficient selection for high-expression transfectants with a novel eukaryotic vector. Gene 1991;108:193-9.

33 Nakagome K, Dohi M, Okunishi K, et al. In vivo IL-10 gene delivery suppresses airway eosinophilia and hyperreactivity by down-regulating APC functions and migration without impairing the antigen-specific systemic immune response in a mouse model of allergic airway inflammation. $\mathrm{J}$ Immunol 2005; 174:6955-66.

34 Okunishi K, Dohi M, Nakagome K, et al. A novel role of cysteinyl leukotrienes to promote dendritic cell activation in the antigen-induced immune responses in the lung. J Immunol 2004;173:6393-402.

35 Tanino Y, Makita H, Miyamoto K, et al. Role of macrophage migration inhibitory factor in bleomycin-induced lung injury and fibrosis in mice. Am J Physiol Lung Cell Mol Physiol 2002;283:L156-62.

36 Tran PL, Weinbach J, Opolon P, et al. Prevention of bleomycin-induced pulmonary fibrosis after adenovirus-mediated transfer of the bacterial bleomycin resistance gene. J Clin Invest 1997;99:608-17.

37 Khalil N, Whitman C, Zuo L, et al. Regulation of alveolar macrophage transforming growth factor- $\beta$ secretion by corticosteroids in bleomycininduced pulmonary inflammation in the rat. J Clin Invest 1993;92:1812-8.

38 Fernandez S, Jose P, Avdiushko MG, et al. Inhibition of IL-10 receptor function in alveolar macrophages by Toll-like receptor agonists. J Immunol 2004:172:2613-20.

39 Avdiushko R, Hongo D, Lake-Bullock $\mathrm{H}$, et al. IL-10 receptor dysfunction in macrophages during chronic inflammation. J Leukoc Biol 2001;70:624-32.

40 Sheppard D, Cohen DS, Wang A, et al. Transforming growth factor $\beta$ differentially regulates expression of integrin subunits in guinea pig airway epithelial cells. J Biol Chem 1992;267:17409-14. 